\title{
The Environmental Impact Assessment in Aquaculture Projects in Chile: A Retrospective and Prospective Review Considering Cultural Aspects
}

\author{
Dante Rodríguez-Luna ${ }^{1,2}$, Nuria Vela ${ }^{3}$, Francisco Javier Alcalá ${ }^{2,4}\left(\mathbb{D}\right.$ and Francisco Encina-Montoya ${ }^{5, *}$ \\ 1 Department of Civil Engineering, Catholic University of Murcia, 30107 Murcia, Spain; \\ derodriguez@alu.ucam.edu \\ 2 Instituto de Ciencias Químicas Aplicadas, Facultad de Ingeniería, Universidad Autónoma de Chile, \\ Santiago 8910060, Chile \\ 3 Applied Technology Group to Environmental Health, Faculty of Health Science, \\ Catholic University of Murcia, 30107 Murcia, Spain; nvela@ucam.edu \\ 4 Geological Survey of Spain (IGME-CSIC), Ríos Rosas 23, 28003 Madrid, Spain; fj.alcala@igme.es \\ 5 Nucleus of Environmental Studies, Catholic University of Temuco, Temuco 4781312, Chile \\ * Correspondence: fencina@uct.cl; Tel.: +56-9-981-733-04
}

Citation: Rodríguez-Luna, D.; Vela, N.; Alcalá, F.J.; Encina-Montoya, $\mathrm{F}$. The Environmental Impact Assessment in Aquaculture Projects in Chile: A Retrospective and Prospective Review Considering Cultural Aspects. Sustainability 2021, 13, 9006. https://doi.org/10.3390/ su13169006

Academic Editors: Ana Villarroya and Jordi Puig

Received: 1 June 2021

Accepted: 4 August 2021

Published: 12 August 2021

Publisher's Note: MDPI stays neutral with regard to jurisdictional claims in published maps and institutional affiliations.

Copyright: (c) 2021 by the authors Licensee MDPI, Basel, Switzerland. This article is an open access article distributed under the terms and conditions of the Creative Commons Attribution (CC BY) license (https:/ / creativecommons.org/licenses/by/ $4.0 /)$.
Abstract: In recent years, social and environmental conflicts concerning the aquaculture sector have increased. These conflicts arise from the different perception that individuals, collectives, private companies and the State have about the potential impacts of aquaculture on the environment and quality of life. The Environmental Impact Assessment (EIA) of aquaculture projects in Chile is the main administrative tool for decision-making, allowing identify, predict, and propose preventive measures to mitigate negative consequences of this growing sector. This article analyzes the performance of the EIA in Chile concerning aquaculture projects between 1994 and 2019. Of the 5323 projects entering the Chilean EIA during this period, the EIA system-performance analysis selected the 71 most representative. For a reliable comparative analysis, the selected projects were first classified in accordance with the active regulation within the period. Subsequently, 14 performance indicators were selected and similarities — by means of a principal coordinate analysis-were explored. Significant differences between the third (SD40) and the first two (SD30 and SD95) regulations were observed. Based on these results and considering demands of local communities and social leaders (who request continuous articulations among technical areas, administrative tools, and policies to increase the sustainability standards of aquaculture), four opportunities for improving the EIA in aquaculture projects are proposed: incorporation of synergistic and cumulative effects, adaptation to climate change, development of a general methodology, and incorporation of early citizen participation (in projects having environmental charge) increasing the performance and confidence of the EIA. The introduced methodology enables comparisons of the EIA process in different regulatory periods using indicators, serving as guidance to evaluate the performance of the EIA in aquaculture. This methodology can also be used by other aquaculture producing countries around the world.

Keywords: environmental impact assessment; aquaculture; Chile

\section{Introduction}

\subsection{Aquaculture in the World}

The aquaculture industry has recorded a noticeable growth in the last 60 years with world population increase and healthier protein-based diet demand [1]. In 2018, the global production of fish, crustaceans, mollusks, and other aquatic animals reached 179 million tons, from which around 82.1 million tons (46\%) were produced in aquaculture systems, representing an increase of $25.7 \%$ regarding the fraction contributed in 2000 . World production in the 2001-2018 period showed an average annual growth of 5.3\%, with China, 
India, Indonesia, Vietnam, Bangladesh, Norway, Egypt, Chile, Myanmar, and Thailand, as main producers. Together, they contribute to ca. $89 \%$ of world production $[1,2]$.

Aquaculture production is the main source of fish for human consumption, being a solution in relation to the deterioration of fishing reserves and the excessive capture of fish in their natural habitat [2]. In the coming years the aquaculture industry will be one of the main sources of food produced in the sea, surpassing traditional fishing. This is how the aquaculture sector contributes to the Sustainable Development Goals (SDG), in particular to the fulfillment of goal 14 "Life below water", but production must be sustainable in order to meet goal 12 "responsible consumption and production" [3-5].

\subsection{Aquaculture in Chile}

The Chilean aquaculture industry has followed similar exponential growth compared to its international counterparts since the 1990s. In 2019, Chile had 2297 aquaculture centers devoted mostly to the cultivation of introduced species such as salmonids, representing around $78 \%$ of the national production and $2 \%$ of the international aquaculture market [6]. Nowadays, Chile is the second producer of salmon worldwide after Norway, growing mainly Atlantic salmon (Salmo Salar), rainbow trout (Oncorhynchus mykiss), and coho salmon (Oncorhynchus kisutch), all of which are introduced species [7]. There are 388 continental (freshwater) cultivation centers, most concentrated in southern Chile, with productions of 228.8 million juveniles and smolt for fattening and subsequent harvesting in the marine phase, which is mainly carried out in inland seas and bays [6,8]. The other species used in aquaculture are mainly concentrated in the Austral Zone (Los Lagos, Aysén, and Magallanes regions). In 2014, the production in these regions reached 99\% of the total harvest, including algae and mollusks. As observed, the Chilean aquaculture industry is concentrated in the cold and wet southern regions, although some mountain areas in the northern Atacama and Coquimbo regions exhibit proper environmental conditions for freshwater aquaculture of oysters, algae, and abalones [9]. This activity represents a noticeable income to the local economy of these regions.

In Chile, aquaculture activity produces different environmental impacts, which include discharge of effluents to freshwater bodies and to the sea, incorporation of feces, uneaten food, suspended solids and dissolved nutrients such as nitrogen, phosphorus and carbon $[10,11]$. In addition, the presence of pharmaceuticals and high salt concentrations in the effluents have also been identified, thus potentially modifying the conditions of the ecosystem and the metabolism of the recipient organisms [12,13]. Additionally, these impacts could increase in the future due to climate change. In southern Chile, a $0.5^{\circ} \mathrm{C}$ increase in temperature and $15 \%$ decrease in precipitation could decrease river flow, thus affecting the production of juveniles and smolts in fresh water [14]. On the other hand, in crops in the fattening phase, a temperature increase could influence the generation of harmful algae blooms (HABs) whereas an oxygen decrease would increase crops mortality [15]. The aforementioned environmental effects have generated growing social distrust around the aquaculture industry, that could increase in the future due to climate change [16].

The environmental impacts and risks described in seawater farming refer to the proliferation of diseases and the overcoming of nutrient loading capacities. In the Patagonian channels and fjords where these farms are located, the seabed eutrophication has affected both benthic diversity and associated trophic chains [7]. Additionally, the use of pharmaceuticals (mostly antibiotics, disinfectants, and antiparasitics for sanitary control) can affect untargeted species, altering local diversity [8]. However, a guide for feasible improvements and mitigation measures is far from being achieved due to the lack of specific supporting studies regarding the understanding of aquaculture activities effects on structure and functioning of freshwater and marine water ecosystems.

From a social point of view, there are permanent socio-environmental conflicts between individuals, organizations, private companies and the State, which is manifested publicly through divergences in opinions, positions, interests and claims for the affectation (or potentiality impact) derived from the access and use of natural resources, as well as the 
environmental impacts of economic activities that would arise since sustainability would not be incorporated as a fundamental principle [17,18]. In this sense, the Environmental Impact Assessment (EIA) is the main tool for decision-making aimed at advancing evaluations of aquaculture projects and its potential impacts as well as at promoting measures to minimize repair. In addition, the EIA establishes the set of reference standards to evaluate compliance with the supervision process in the operation stages and abandonment of the projects.

\subsection{Environmental Impact Assessment in Aquaculture Projects}

In 1994, the Chilean Environmental Impact Assessment (EIA) system was created within the framework of Law 19,300 of Bases Generales del Medio Ambiente (General Environmental Bases, GEB). Between 1994 and 2020 there have been two amendments of the Reglamento del Sistema de Evaluación de Impacto Ambiental (Environmental Impact Assessment System Regulation, EIASR), the former being the Decreto Supremo $N^{\circ} 30$ (Supreme Decree SD30) [19] and the later the Decreto Supremo $N^{\circ} 95$ (Supreme Decree SD95) [20]. In 2010, the Servicio de Evaluación Ambiental (Environmental Assessment Service, EAS) was created, as ruling institution for the administration of the EIA in Chile [21,22]. In 2012, a third amendment of the EIASR was introduced through the Decreto Supremo $N^{\circ} 40$ (Supreme Decree SD40) [23]. Figure 1 shows the chronological flow of the main EIA regulation items accounted in Chile from 1994 to present.

Law 19,300

enacted on 1

March 1994
SD95

enacted on 21

August 2001.

Repeal SD30
SD40

enacted on 30

October 2012.

Repeal SD95

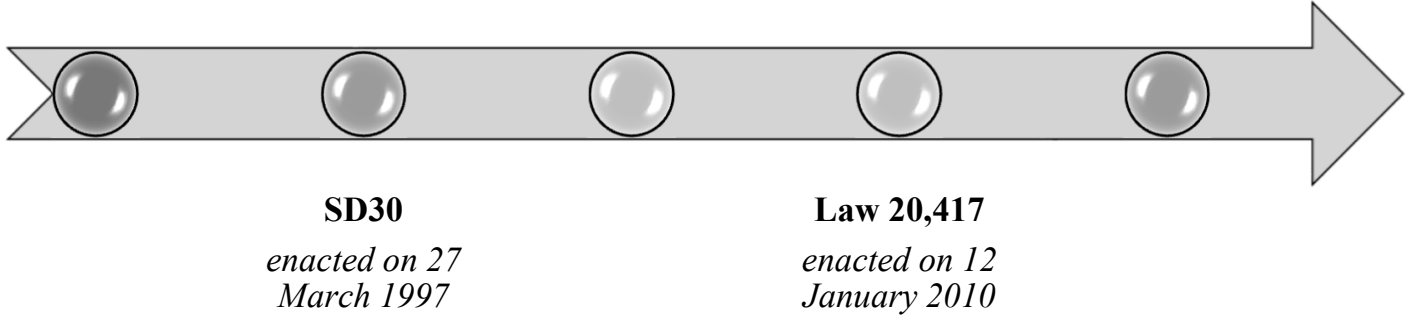

Figure 1. From 1994 to the present, chronological flow of the main EIA Laws and Supreme Decrees (SD) in Chile.

Projects entering the EIA are defined in article 10 of Law 19,300 and detailed in article 3 of the SD40, from letter ' $a$ ' to 's'. For instance, 'type h. 2 includes industrial projects in a saturated area with surface up to 20 hectares or that generate more than $5 \%$ of the total daily emission in relation to the pollutants for which the area was declared saturated', 'type k.1 includes industrial projects with installed power equal to or higher than $2000 \mathrm{KVA}^{\prime}$, and 'type $\mathrm{n}$ includes projects of intensive exploitation, cultivation and processing plants of hydrobiological resources'.

In the current EIASR (article 3 in SD40) an environmental assessment is mandatory for the following aquaculture projects [23]: (i) n.1: for macroalgae, an annual production equal or higher than 500 tons and/or equal or higher acreage than 100,000 square meters. (ii) n.2: for filter feeders, an annual production equal or higher than 300 tons and/or equal or higher acreage than 60,000 square meters; for other extensively produced, mechanically filtered species, an annual production equal or higher than 40 tons. (iii) n.3: for intensively produced echinoderms, no filter feeders, crustaceans and mollusks, fish, and other species, an annual production equal or higher than 35 tons. (iv) n.4: for cultivations of any hydrobiological resource in navigable rivers without affecting the tide of those produced in non-navigable rivers or lakes whatever its annual production, an annual production equal or higher than 15 tons. (v) n.5: for fish, microalgae culture, and/or juveniles of others hydrobiological resources that require supply and/or evacuation of continental, marine, or estuarine waters sources, whatever its annual production, an annual production 
equal or higher than eight tons. Likewise, it will be understood by processing plants of hydrobiological resources, the facilities factories whose objective is the elaboration of products through total or partial transformation of any hydrobiological resource or its parts, including process plants of on board factories or factory ships, which use as raw material an amount equal or higher than 500 tons per month of biomass in the month of maximum production; waves plants that meet the requirements indicated in the types h. 2 or k.1.

The Chilean law considers projects entering the EIA for evaluation as Estudio de Impacto Ambiental (Environmental Impact Study, EIS) and Declaración de Impacto Ambiental (Environmental Impact Declaration, EID) [23]. An EIS is a document where all the characteristics of the project - to be executed-are described in detail. The report must contain all background information on prediction, identification and interpretation of the environmental impacts, and must describe how significant adverse effects are prevented or minimized. An EID, on the other hand, is a project report, under oath of the owner, where its content allows for an environmental impact evaluation in accordance with the environmental law [21,22]. Regardless of the EIA entry route, projects must comply with the specifications that regulate the activity, for instance (1) Decreto Supremo $N^{\circ} 320$-Reglamento Ambiental para la Acuicultura (Supreme Decree for Aquaculture Environmental Regulation, RAMA) includes aspects related to the characteristics of the culture and the emplacement; (2) Decreto Supremo $N^{\circ} 319$-Reglamento Sanitario (Supreme Decree for Sanitation Regulation, RESA) incorporates control measures to prevent diseases; (3) Decreto Supremo $N^{\circ}$ 90-Norma de emisión para la regulación de contaminantes asociados a las descargas de residuos líquidos a aguas marinas y continentales superficiales (Supreme Decree for Emission Standard of Liquid Water discharges to Surface Marine and Continental Waters, ESLW) regulates pollutants emission to marine and continental waters [24-26].

The EIA is an instrument subjected to constant renovation in order to consider the permanent environmental sensitivity in relation to the presented and approved projects, as many of these trigger environmental conflicts in the territories [27]. In fact, Chile is one of the countries having more environmental conflicts; for instance, in 2018 Chile was the 14th of 181 countries in the Environmental Justice Atlas [28]. According to data reported by the Instituto Nacional de Derechos Humanos (National Institute for Human Rights, NIHR), in 2020 there were 118 environmental conflicts in Chile, 37\% being related to energy, $28 \%$ to mining, $8 \%$ to environmental sanitation, and $27 \%$ to other sectors including aquaculture $[29,30]$. Conflicts are partly due to the normal mismatching between current regulation (which changes fluently but not immediately) and the perception of mistrust by society regarding the EIA, since in its opinion it does not solve problems or consider its concerns [27].

After a scientific rational analysis of these and other conflicts, Rodríguez-Luna et al. [31] identified the main strengths and weaknesses of the Chilean EIA system. The authors compared 18 evaluation criteria defined in the scientific literature [32-35] and four additional criteria expressly proposed on the basis of identified environmental conflicts in Chile. The main strengths were legal basis, existence of defined deadlines for each stage, administrative support, existence of a competent authority, consultation and participation, and existence of Environmental Courts specialized in dispute resolution. Among the weaknesses: a system with high centralization at the national level, absence of mandatory obligation of project-design alternatives, non-existence of the scoping, and Strategic Environmental Assessment (SEA) not binding [31].

As described above, aquaculture is one of the economic drivers in Chile [9], which will rapidly increase with population growth and as new healthy-feeding habits progressively permeate society. However, aquaculture involves a negative potential effect on the environment, and new conflicts may arise ahead. This fact, together with the available methodology proposed by Rodríguez-Luna et al. [31] for identifying the main strengths and weaknesses of the Chilean EIA system, makes the introduction of a methodology for 
evaluating the Chilean EIA system performance (concerning aquaculture activity) feasible (and necessary), in agreement with goals 12 and 14 of the SDG.

This article evaluates the Chilean EIA system performance concerning aquaculture activity. For this, (1) a state-of-the-art in assessing the environmental impact of aquaculture projects is described, (2) suitable indicators to catalogue a representative sample of aquaculture projects are identified and evaluated, and (3) some improvements to increase the performance standard of the EIA in aquaculture are proposed.

\section{Materials and Methods}

\subsection{Study Area}

Chile is in southwest of South America, has a length of $4200 \mathrm{~km}$ of continental territory, and $8000 \mathrm{~km}$ if the Antarctic territory is considered. Chile includes a maritime area of $3.15 \mathrm{Mkm}^{2}$ in its exclusive economic zone of 200 nautical miles, and its coasts are productive ecosystems giving a great advantage as a producer of demanded fisheries and aquaculture resources in the international markets. For geographical guidance, Figure 2 shows the macrozones and regions division of Chile.
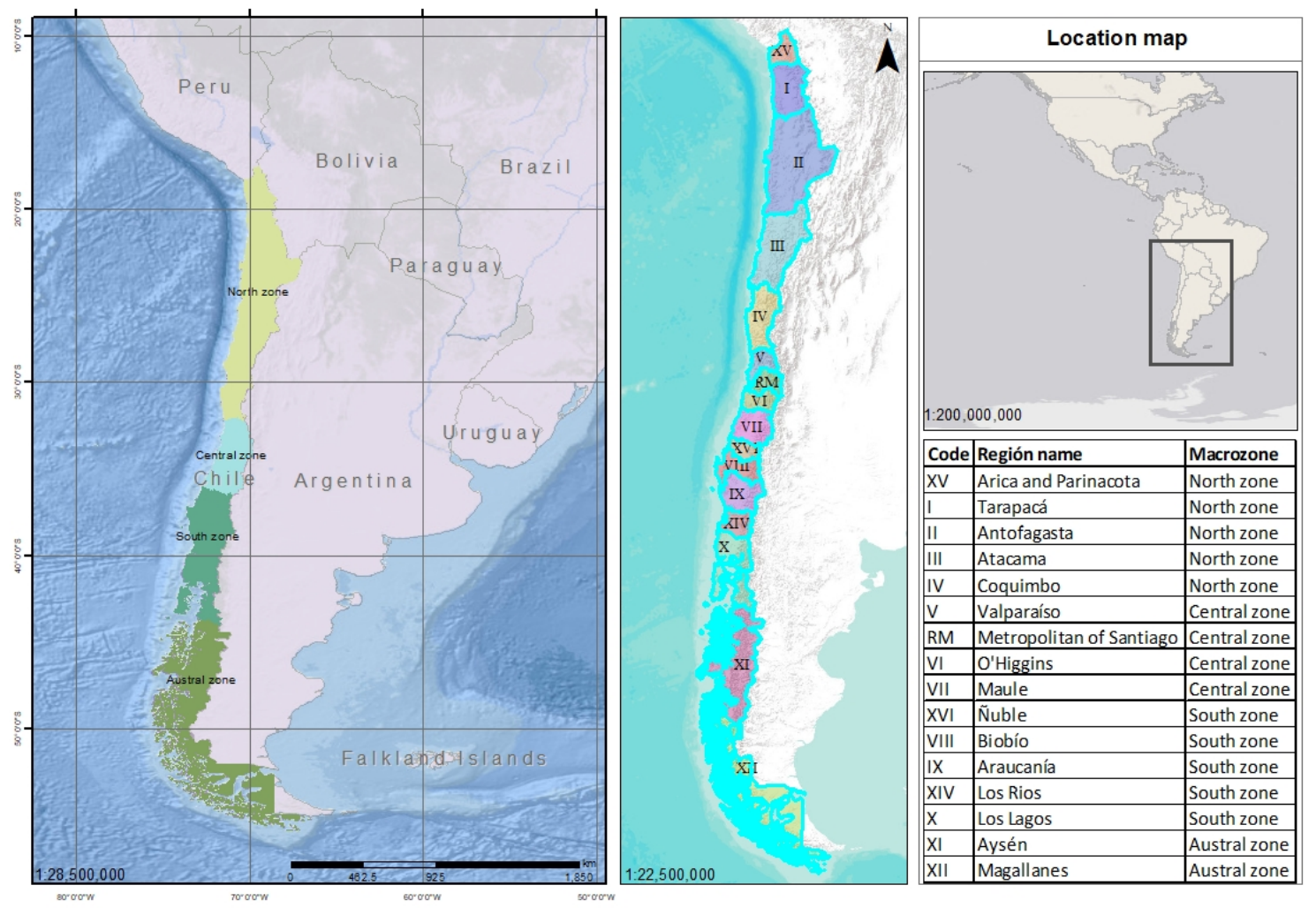

Figure 2. The Chilean macrozones and regions.

The Chilean aquaculture currently produces several species of fish, mainly salmon, trout, and turbot in minor amount. It also produces shellfish, among which the mussel (Mytilus chilensis), scallops, Pacific oysters and, to a lesser extent, giant mussels or cholga (Aulacomya ater), red abalone, and Chilean oysters, along with species of algae called pelillo stand out (Agarophyton chilensis). The Chilean aquaculture is mainly located at coastal marine farms, particularly in the Los Lagos, Aysén, and Magallanes regions, where the main products are salmon and trout, along with mussel mussels and algae. Significant volumes northern scallops, abalone, and pelillo algae are also produced in the Coquimbo and Atacama regions [6]. 


\subsection{Data Source}

All the 'type $\mathrm{n}$ ' aquaculture projects registered in the official EAS website [https: / / www.sea.gob.cl/] were compiled [23]; data were accessed on 1 December 2020. The selection covered both presented and approved EIS and EID projects from 1994 to 2019. For an intuitive analysis, projects were ordered by region, and independently of status and regulation in force [36,37].

\subsection{Selection of Projects}

A probability sampling analysis to determine the accurate sample size was used [38]. The sample was obtained by using a proportional stratified sampling method for a finite population, taking the confident levels of $10 \%$ and $90 \%$ into account as error thresholds to exclude projects $[39,40]$. The finite population included the approved 5323 aquaculture projects between 1994 and 2019, classified by region (strata). The basic formulation was:

$$
\eta=\frac{N Z^{2} P Q}{e^{2}(N-1)+Z^{2} P Q}
$$

where $\eta=$ sample size,$e=$ sample error, $N=$ population size, $P=$ percentage of individuals with particular characteristics, $Q=$ percentage of individuals not having a particular characteristic, and $Z=$ imposed confidence level.

Projects were randomly selected after imposing the following causes for exclusion of those covering two or more regions (interregional), being addenda or modification only, rejected, not admitted for processing, withdrawn, revoked, and not evaluated. The selected projects-by macrozone in Chile-are presented in Table 1. See Figure 2 for macrozones and regions in Chile.

Table 1. Selected projects in each macrozone of Chile.

\begin{tabular}{ccc}
\hline \multirow{2}{*}{ Macrozone $^{1}$} & \multicolumn{3}{c}{ Selected Projects } \\
\cline { 2 - 3 } & EIS & EID \\
\hline North Zone & 1 & 3 \\
South Zone & 2 & 41 \\
Austral Zone & & 24 \\
\hline
\end{tabular}

${ }^{1}$ Figure 1 displays macrozones and regions in Chile.

\subsection{Selection of Indicators}

This analysis was mainly focused on the EIA process. On the basis of a systematic review of electronic files from the official EAS website, a set of indicators were identified as reliable for carrying out a comparison of the projects produced during the three regulatory stages, both SD30, SD95, and SD40 as shown in Figure 1. Table 2 contains the selected 14 indicators, as well as their codification from $\mathrm{A}$ to $\mathrm{N}$, description, and the assigned scores.

The selected criteria were Processing time (A), Description and justification of the influence area (B), Professionals who prepared reports are included (C), Methodology to identify and evaluate environmental impacts (D), Number of participating institutions in the project evaluation $(\mathrm{E})$, Use of international regulations as a reference $(\mathrm{F})$, Existence of mitigation measures $(\mathrm{G})$, Existence of repair measures $(\mathrm{H})$, Identification of contingency and emergency measures (I), Consultation and participation (J), Appeal after project approval or rejection (K), Supervision and punishment for non-compliance (L), and Initial status (N). Some specifications are described below. Criteria A, B, C, L, and N used an ordinal ranking in the 1-5 range for a quantitative scoring. Criteria D, F, G, H, I, J, and K used a nominal scale (Yes or No) for a qualitative scoring [41,42]. The criterion $E$ used a continuous numerical scale (Table 2). 
Table 2. Selected indicators to compare the aquaculture projects under the SD30, SD95, and SD40 regulatory stages.

\begin{tabular}{|c|c|c|c|c|c|}
\hline Indicator & Description & Reference for Original Criterion & Code & Description & Score \\
\hline Processing time (working days) & $\begin{array}{l}\text { It corresponds to the processing time in each } \\
\text { project, which is related to the deadlines } \\
\text { established for the EIA }\end{array}$ & $\begin{array}{l}\text { Adapted from Annandale [33] and } \\
\text { Rodríguez-Luna et al. [31] }\end{array}$ & $\mathrm{A}$ & $\begin{array}{l}\geq 361 \\
271-360 \\
181-270 \\
91-180 \\
1-90\end{array}$ & $\begin{array}{l}1 \\
2 \\
3 \\
4 \\
5\end{array}$ \\
\hline $\begin{array}{l}\text { Description and justification of } \\
\text { the influence area }\end{array}$ & $\begin{array}{c}\text { It is the area where the environmental impacts } \\
\text { of the project are manifested. Definition of the } \\
\text { influence area is linked to the baseline } \\
\text { information }\end{array}$ & Adapted from Rodríguez-Luna et al. [31] & B & $\begin{array}{l}\text { No information about the influence area } \\
\text { Information not justified } \\
\text { General information only } \\
\text { Moderately justified information } \\
\text { Detailed and justified information }\end{array}$ & $\begin{array}{l}1 \\
2 \\
3 \\
4 \\
5\end{array}$ \\
\hline $\begin{array}{l}\text { Professionals who prepared } \\
\text { reports are included }\end{array}$ & $\begin{array}{l}\text { The team or professionals who prepared the } \\
\text { report, which can influence over the } \\
\text { information quality }\end{array}$ & CAPSEIA [27] & 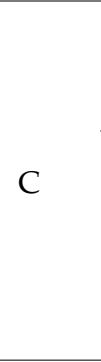 & $\begin{array}{l}\text { Project developer is unknown } \\
\text { Mention of the developer consulting } \\
\text { company only } \\
\text { Details people who developed the project, } \\
\text { but not their experience } \\
\text { Details people who developed the project } \\
\text { and function, but not their experience } \\
\text { Details professional title and function of } \\
\text { each person involved in the project }\end{array}$ & $\begin{array}{l}3 \\
4 \\
5\end{array}$ \\
\hline $\begin{array}{l}\text { Methodology to identify and } \\
\text { evaluate environmental impacts }\end{array}$ & $\begin{array}{l}\text { Method used to identify and evaluate the } \\
\text { environmental impacts of a project }\end{array}$ & CAPSEIA [27] & $\mathrm{D}$ & $\begin{array}{l}\text { Yes } \\
\text { No }\end{array}$ & $\begin{array}{l}2 \\
1\end{array}$ \\
\hline $\begin{array}{l}\text { Number of participating } \\
\text { institutions in the project } \\
\text { evaluation }\end{array}$ & $\begin{array}{l}\text { Public institutions that participate in the } \\
\text { project review }\end{array}$ & None & $\mathrm{E}$ & A continuous numerical scale was used & $\mathrm{NA}^{1}$ \\
\hline $\begin{array}{l}\text { Use of international regulations } \\
\text { as a reference }\end{array}$ & $\begin{array}{l}\text { Regulations from other countries that can be } \\
\text { used when there is not national legislation }\end{array}$ & CAPSEIA [27] & $\mathrm{F}$ & $\begin{array}{l}\text { Yes } \\
\text { No }\end{array}$ & $\begin{array}{l}2 \\
1\end{array}$ \\
\hline Existence of mitigation measures & Set of actions to reduce environmental impact & $\begin{array}{l}\text { Ahmad and Wood [34] and Rodríguez-Luna } \\
\text { et al. [31] }\end{array}$ & G & $\begin{array}{l}\text { Yes } \\
\text { No }\end{array}$ & $\begin{array}{l}2 \\
1\end{array}$ \\
\hline Existence of repair measures & $\begin{array}{l}\text { Set of actions to replace the environmental } \\
\text { impact generated }\end{array}$ & $\begin{array}{l}\text { Ahmad and Wood [34], and Rodríguez-Luna } \\
\text { et al. [31] }\end{array}$ & $\mathrm{H}$ & $\begin{array}{l}\text { Yes } \\
\text { No }\end{array}$ & $\begin{array}{l}2 \\
1\end{array}$ \\
\hline $\begin{array}{l}\text { Identification of contingency and } \\
\text { emergency measures }\end{array}$ & $\begin{array}{l}\text { Measures for emergency and contingency } \\
\text { response to accidental events }\end{array}$ & Ahmad and Wood [34] & I & $\begin{array}{l}\text { Yes } \\
\text { No }\end{array}$ & $\begin{array}{l}2 \\
1\end{array}$ \\
\hline
\end{tabular}


Table 2. Cont

\begin{tabular}{|c|c|c|c|c|c|}
\hline Indicator & Description & Reference for Original Criterion & Code & Description & Score \\
\hline Consultation and participation & $\begin{array}{l}\text { Instance where citizens are involved in a participatory } \\
\text { way in the project }\end{array}$ & $\begin{array}{l}\text { Wood [32], Ahmad and Wood [34], Khosravi } \\
\text { et al. [35], and Rodríguez-Luna et al. [31] }\end{array}$ & $\mathrm{J}$ & $\begin{array}{l}\text { Yes } \\
\text { No }\end{array}$ & $\begin{array}{l}2 \\
1\end{array}$ \\
\hline $\begin{array}{l}\text { Appeal after project approval or } \\
\text { rejection }\end{array}$ & $\begin{array}{l}\text { Options to appeal decision after obtaining the } \\
\text { environmental license }\end{array}$ & $\begin{array}{l}\text { Ahmad and Wood [34], and Rodríguez-Luna } \\
\text { et al. [31] }\end{array}$ & $\mathrm{K}$ & $\begin{array}{l}\text { Yes } \\
\text { No }\end{array}$ & $\begin{array}{l}2 \\
1\end{array}$ \\
\hline $\begin{array}{l}\text { Supervision and punishment for } \\
\text { non-compliance }\end{array}$ & $\begin{array}{l}\text { Existence of supervisions to sanction regulations } \\
\text { infractions of the projects subject to EIA }\end{array}$ & Rodríguez-Luna et al. [31] & $\mathrm{L}$ & $\begin{array}{c}\text { No information about supervision } \\
\text { Unsupervised project } \\
\text { Breach of the RCA or Sectorial Permits } \\
\text { Sanction process with reprimand, fine, and/or compliance program } \\
\text { Comply with the inspection and sanction process }\end{array}$ & $\begin{array}{l}1 \\
2 \\
3 \\
4 \\
5\end{array}$ \\
\hline Existence of compensation measures & $\begin{array}{l}\text { Set of actions to produce an alternative positive effect } \\
\text { equivalent to an identified adverse effect }\end{array}$ & $\begin{array}{l}\text { Ahmad and Wood [34], and Rodríguez-Luna } \\
\text { et al. [31] }\end{array}$ & $\mathrm{M}$ & $\begin{array}{c}\text { Yes } \\
\text { No }\end{array}$ & $\begin{array}{l}2 \\
1\end{array}$ \\
\hline Initial status & $\begin{array}{l}\text { Initial condition of the project at the time of entering } \\
\text { the EIA }\end{array}$ & None & $\mathrm{N}$ & $\begin{array}{l}\text { No information } \\
\text { Applying for sectoral permits without RCA } \\
\text { No start of works } \\
\text { Under construction } \\
\text { In operation }\end{array}$ & $\begin{array}{l}1 \\
2 \\
3 \\
4 \\
5\end{array}$ \\
\hline
\end{tabular}




\subsection{Data Analysis}

After preparation of the performance indicators matrix for aquaculture projects, a principal coordinate (PCO) analysis [43] to identify main patterns and relationships between projects, indicators, and regulatory stages was performed. The PCO analysis enables finding similarities between objects and variables, reduces dimensionality, and projects the similarity values between samples, while relevant relationships information between a set of objects is preserved. Data structure analyzed in a PCO analysis is a similarity (or distance) matrix for a set of objects. The PCO analysis is suitable for any similarity matrix, distance in which the normality conditions are not fulfilled (e.g., due to multinormality) and the number of variables exceeds the sample $[44,45]$. In this study, the variables were square-root transformed and the result standardized by the total. Later, a similarity matrix based on Euclidean distance was created [45], an ANOVA analysis with permutational multivariate analysis of variance (Permanova) was implemented, and a hierarchical cluster analysis by using the Simprof test was performed. This test used 999 permutations over a $5 \%$ significance level to identify and validate the potential effect of the different regulations (SD30, SD95, and SD40) on the association of projects with performance indicators. The Primer 7 v7.0.13 program from Primer-e 2020 was used for numerical analysis and graphical plotting.

\section{Results and Discussion}

\subsection{The Chilean Aquaculture Projects}

From 1994 to 2019, a total of 5323 aquaculture projects were submitted to the Chilean EIA system. Regarding the route chosen for evaluation, 35 projects $(0.66 \%)$ were presented as EIS and $5288(99.34 \%)$ as EID. The regions having the larger number of submitted projects were Los Lagos (2257 projects) in the South Zone, Aysen (1862 projects), and Magallanes (386 projects) in the Austral Zone. These three regions cover $84.6 \%$ of the total projects submitted in Chile. The figures are consistent with the findings reported by Lacy [36]. Regarding the status of the projects, $68.9 \%$ were approved, $9.4 \%$ rejected, $0.1 \%$ in evaluation, $10.7 \%$ unadmitted, $1.7 \%$ no rated, $0.2 \%$ abandoned, $8.8 \%$ desisted, and $0.2 \%$ had an expired license. Figure 3 displays the percentage of EIS and EID aquiculture projects by status (approved and causes for rejection) and region.

For the period 1994-2019, a more detailed analysis by region was conducted; see results in Figure 3. O'Higgins in the Central Zone and Los Lagos in the South Zone were the regions having the larger percentages of projects approval. However, it is important to highlight that 2257 were submitted in Los Lagos whereas only 3 projects were submitted in $\mathrm{O}^{\prime}$ Higgins. Thus, this finding is skewed and at least tentative.

In relation to the rejected projects by region, the higher percentages were found in Antofagasta (20\%) in the North Zone, Nuble (17.6\%) in the South Zone, and Aysen $(14.7 \%)$ in the Austral Zone. For interregional projects, the rejection percentage was $16.7 \%$. The main causes for rejection were non-compliance regulatory, no Permisos Ambientales Sectoriales (Sectorial Environmental Permits, SEP) granting, generation of the effects, characteristics and circumstances of articles 5-10 from the EIASR [23].

Regarding the unadmitted projects by region, the higher percentages were found in Valparaiso (36.4\%) in the Central Zone and Coquimbo (31.1\%) in the North Zone. It is important to consider that all projects are analyzed through the identical admissibility test, attending all to minimum content requirements established in articles 18 and 19 from the EIASR [23,31]. The high percentage of non-admitted projects was of recent research. After analyzing all causes for non-admitting projects, the Coquimbo region had not admitted $51 \%$ of the projects submitted in the predetermined deadline [46]. The admissibility test only refers to the existence or inexistence of the information (checklist). Differences in criteria were identified when applying the admissibility test, since in some cases the quality of the information was analyzed.

Regarding the non-qualified projects, the higher percentages were found in Bio Bio $(13 \%)$ and Los Ríos (11.9\%) regions in the South Zone. The cause is lack of relevant or 
essential information for a confident evaluation of the project, which implies early closure of the procedure [20]. It is worth mentioning that this procedure was included in the last modification of the EIASR, constituting one of the most significant changes in the Chilean regulation $[22,47]$.

\section{(a)}

\section{Macrozone Region}

North Zone

South Zone

Austral Zone

(b) Macrozone Region

North Zone XV, Arica and Parinacota

I, Tarapacá

II, Antofagasta

III, Atacama

IV, Coquimbo

V, Valparaíso

Central Zone

South Zone

Austral Zone RM, Metropolitan

VI, O'Higgins

VII, Maule

XVI, Nuble VIII, Bio Bio

IX, La Araucanía

XIV, Los Ríos

$X$, Los Lagos

$\mathrm{XI}$, Aysén

XII, Magallanes

$$
0 \%
$$

Approved

No rated

\section{nejected In evaluation Unadmitted}

- Abandoned Desisted $\quad$ License expired

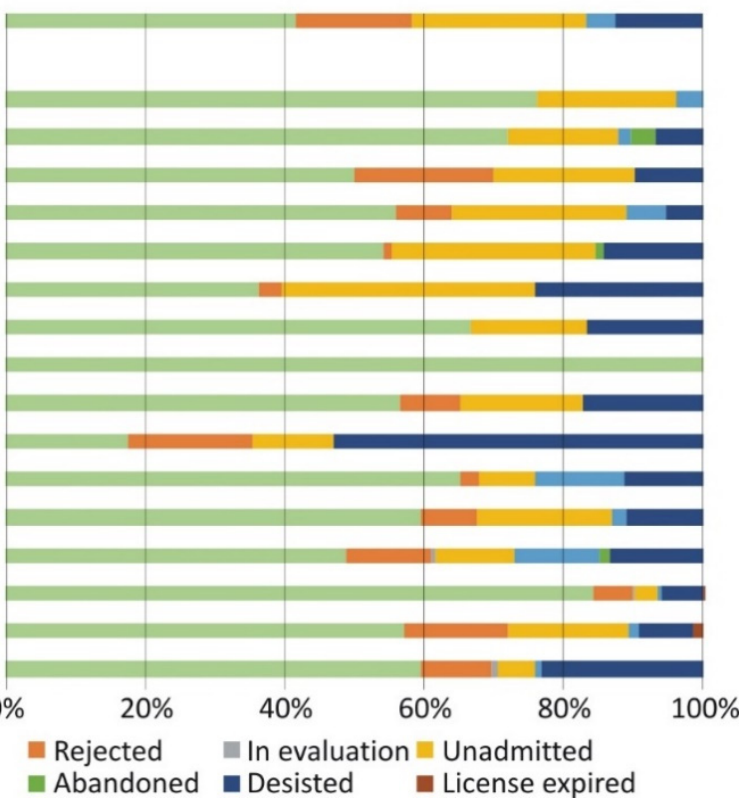

Figure 3. From 1994 to 2019, percentage of EIS (a) and EID (b) by macrozone and region. Regions with data are considered only. Basic information is available in Table A1 in Appendix A.

\subsection{Multivariate Analysis of Indicators}

A sample of 71 projects was obtained from information available on the official EAS website (68 EID and 3 EIS). Subsequently, the PCO analysis was applied to explore (1) patterns between projects through their relationship with the 12 selected indicators (criteria $\mathrm{M}$ and $\mathrm{N}$ were excluded because they do not provide statistical variability) and (2) how each regulatory stage (SD30, SD95, and SD40) determines the variability of the 68 EID projects analyzed; the EIS projects were excluded from this analysis. Figure 4 shows the first factorial plane (PCO1 and PCO2), which represents $55.2 \%$ of the sample total variance. This first factorial plane identifies two groups. Group 1 includes projects from the first (SD30) and second (SD95) regulatory stage. Findings correlate with the indicators Existence of mitigation measures $(\mathrm{G})$, Existence of compensation measures $(\mathrm{H})$, and Supervision and punishment for non-compliance (L). Group 2 mostly includes projects from the third regulatory stage (SD40). Findings correlate well with the indicators Processing time (A), Use of international regulations as a reference $(\mathrm{F})$, and Consultation and participation (J). The full list of PCO analysis coordinates is presented in Table A2 in Appendix A. The causes determining the relationships between indicators and projects are briefly described and discussed below. 


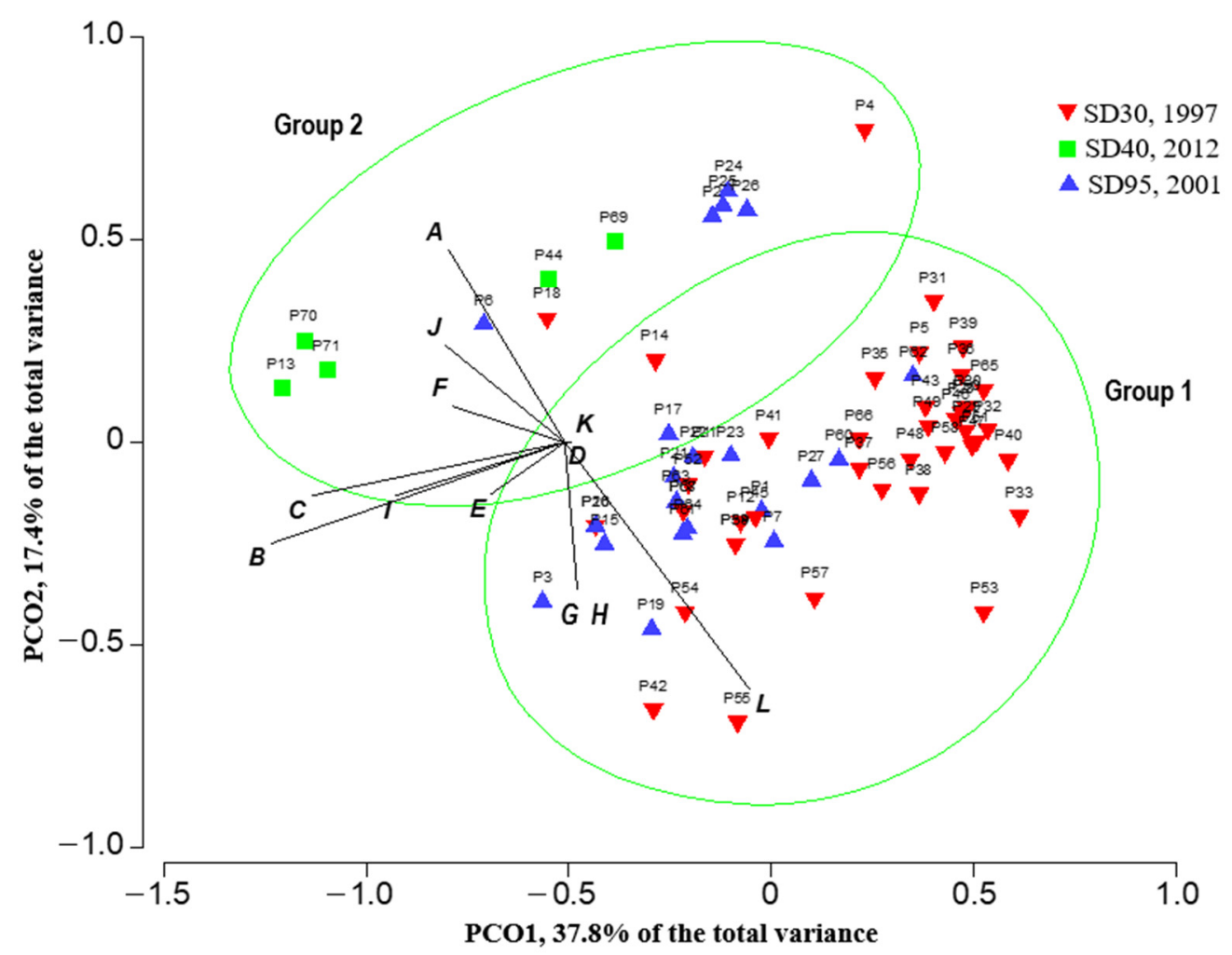

Figure 4. Results from the principal coordinate (PCO) analysis, showing the first factorial plane PCO1 and PCO2 of projects entering as EID (68 samples); this attempt does not consider projects entering as EIS. A to L denote the 14 indicators as in Table 2. The full list of coordinates of the PCO analysis is presented in Table A2 in Appendix A.

Processing Time (A). The results are sensitive to the three regulatory stages because the legal time progressively decreased from SD30 to SD40. This is explained by the requirements of the current regulation, which establishes a processing time of 120 days extendable to a maximum of 180 days for EIS, and 60 days extendable to a maximum of 90 days for EID [23].

Description and justification of the influence area (B). The projects approval performance shows a significant improvement from SD30 to SD40. This fact maintains the relationship with the EIA evolution toward a better description of essential elements such as the influence area. In this sense, the EAS has endeavored to create guides for description and use of the territory [48]; description of soil, flora, and fauna components [49]; air quality in the influence area [50]; influence area [51]; influence area for life systems and human group customs [52]. These guides improve descriptions and justifications of the influence area incorporated by projects owners.

Professionals who prepared reports are included (C). This indicator varies along the regulatory stages. In general, under the first stage (SD30), the projects do not provided details about the developers or the consulting company. Under the second stage (SD95), 70\% of the projects informed about the consultant company or people taking part; the remainder did not provide this information. In contrast, more than $60 \%$ of the projects under the third regulatory stage (SD40) provided details about each professional participating in the projects and their role. These differences are a consequence of the improvements made after enacting the SD40 [23].

Methodology to identify and evaluate environmental impacts (D). This methodology does not differ along the three regulatory stages because the Chilean regulation does not require introducing specific techniques in the EID projects. Contrastingly, the selected EIS projects used the same methodology based on the 'Leopold Matrix'. For these projects, the three regulatory stages dictated obligation to identify and evaluate the environmental impacts, so other methodologies may be used. 
Number of participating institutions in the project evaluation (E). This indicator showed no significant variation during the first (SD30) and second (SD95) regulatory stages, whereas during the third stage (SD40) the institutions that evaluated the analyzed projects increased by $35 \%$. This strengthened the ability of the EIA for a deeper review of the projects.

Use of international regulations as a reference $(\mathrm{F})$. This is not a common practice in aquaculture projects. Only one of the selected projects was aimed at modeling odors in a fish processing plant.

Existence of mitigation measures (G). This indicator was found across all the selected EIS projects and in $7.35 \%$ of the EID projects submitted under the first regulatory stage (SD30). This is explained by the incorrect conceptualization of some aspects of the EIA, that have been resolved in the new regulatory stages.

Existence of reparation measures $(\mathrm{H})$. This indicator was found in $7.35 \%$ of the EID projects submitted under the first regulatory stage (SD30). It is due to conceptual problems at the beginning of the EIA in Chile.

Identification of contingency and emergency measures (I). This indicator showed differences varying from $36 \%$ of the projects under the first regulatory stage, to $92 \%$ of the projects under the second stage, and $100 \%$ of the projects under the third stage. The regulatory framework is crucial as the current EIARS establishes this indicator as a requirement [23].

Consultation and participation (J). This indicator also showed differences because citizen participation was only included in projects under the third regulatory stage (SD40). For the EID, the Chilean regulation establishes that citizen participation is possible for those projects included in article 94 of the EIASR, so the type ' $n$ ' was not included even though three projects had secondary typologies that allow citizen participation. However, citizen participation was carried out in all EIS since it is mandatory $[23,31]$. In summary, only $8 \%$ of the selected projects included citizen participation, and in $66.6 \%$ of the projects with citizen participation observations were received. The lack of citizen participation was one of the weaknesses identified in the citizen councils held by the Presidential Advisory Commission for the evaluation of the EIA System, where it was stated that effective binding and early participation must be carried out [27,53]. Additionally, even when citizen participation mechanisms exist, this participation is based more on subjective opinions with respect to a perception of risk than on technical reasoning, thus showing an important asymmetry between the holder participation, the State Agencies and the citizenship. In this sense, it would be necessary to explore the State mechanisms that facilitate technical support to people in order to organize cooperation focused on a better and complementary performance of social actors.

Appeal after project approval or rejection $(\mathrm{K})$. In total, $8.5 \%$ of the projects were appealed after obtaining the environmental license, mostly in the SD95 regulatory stage. The Chilean society values the appeal options, but also considers it important to increase the technical capacity, mainly in the Ministerial Committee [27].

Supervision and punishment for non-compliance (L). The results are not conclusive due to difficulties in accessing information of the projects under the third regulatory stage (SD40). The problem arises from the incompatibility between the Superintendence of the Environment and EAS web platforms, as also noticed by Rodríguez-Luna et al. [31]. For the other two former regulatory stages (SD30 and SD95), the electronic file of each project is available, thus favoring transparency and access to information. Transparency and the access to public information are one of the culturally considered most relevant aspects in Chile. In this sense, previous research has developed a proposal to integrate the web platforms of the Superintendency of the Environment and the Environmental Assessment Service, thus improving the standard of this criterion $[27,31]$.

Existence of compensation measures (M). No significant differences attending to the regulatory stage were found.

Initial status $(\mathrm{N})$. All the selected projects were found without beginning works. No significant differences attending to the regulatory stage were found. 


\subsection{Opportunities to Improve EIA from Cultural Lessons}

In Chile, demands of local communities and social leaders are increasing in order to promote a sustainable development of the area. These demands require continuous articulations between technical areas, administrative actions, and policies. Taking into account the subsequent main weaknesses detected in the EIA analysis of aquaculture projects and the cultural lessons of the Chilean society, four opportunities for improvement are proposed. These four improvements can also be extended to other types of projects and will make it possible to improve the overall performance of the EIA, since they consider sociocultural aspects, so that the increase in administrative standard will imply an increase in the level of social confidence. The first improvement is to extend to EID the obligation to consider synergistic and cumulative effects that the EIS currently require [23]. This is a crucial issue because $99.34 \%$ of the projects are evaluated as EID whereas the individual impact is evaluated in the EIA system but not the collective and cumulative impacts over time [54,55]. This aspect is relevant considering that society frequently demands the incorporation of synergistic and cumulative effects in the EID, and currently it is not mandatory.

The second improvement is to include resilient measures to climate change in the project evaluation process, both in EID and EIS. Chile is particularly vulnerable to climate change and is already experiencing its impacts $[56,57]$. In this sense, it must be peremptory to establish the link between the project and climate policies and the resilient measures in relation to the potential impacts $[27,58,59]$. On the other hand, the Chilean society recognizes the effects of climate change, which could affect their way of life and customs, so culturally it is a very relevant aspect to consider [60].

The third improvement is to develop a general methodology to identify and evaluate the environmental impacts in EID, for example, by preparing official guidelines. Nowadays, prediction and evaluation of environmental impacts concern only EIS, i.e., $0.66 \%$ of aquaculture projects. Therefore, article 19 from the EIARS referring to EID (which cover most of aquiculture projects) should also include this requirement. In general, citizens have doubts about the environmental impacts of the projects, especially during the citizen participation processes, so the inclusion of this requirement brings immediate improvements from the point of view of the availability of information and its public perception.

The fourth improvement refers to the mandatory incorporation of early participation in projects having environmental charges, as defined for a secondary typology in the article 94 from the EIARS. In order to reduce the environmental conflict, the project owner must promote early participation before entering the project in EAS [61,62]. Early participation is an opportunity to obtain an early dialogue with the community. This provides clear information on the environmental impacts of the project and the strategy to minimize and control them. This aspect of one of the main permanent citizen demands in relation to the improvement of the EIA process [63,64].

Proposals for improvement imply to raise the environmental evaluation standard through the EIASR modification. However, we must be aware that to improve the sustainability of the aquaculture sector, the interaction of several actors (industry, community and regulatory institutions) is needed to solve this issue.

\section{Conclusions}

A retrospective and prospective review of the EIA system concerning the aquaculture sector in Chile was performed, taking cultural (social and environmental) aspects into account. A total of 5323 aquaculture projects submitted to the EAS from 1994 to 2019 were compiled, $99.34 \%$ being EID projects. From these, $84.6 \%$ were from the Los Lagos region in the South Zone, and Aysén and Magallanes regions in the Austral Zone. Regarding the status of the 5323 projects, $68.5 \%$ were approved, $9.4 \%$ rejected, and $10.7 \%$ not admitted. The O'Higgins region (100\%) in the Central Zone and Los Lagos (84\%) region in the South Zone showed the higher approval rate. On the contrary, Antofagasta region (20\%) in the North Zone and Nuble region (17.6\%) in the South Zone showed the higher rejection rate. 
Valparaíso and Coquimbo regions in the North Zone record the highest percentages of unadmitted projects.

A PCO analysis that selected a representative sample of projects to analyze the Chilean EIA system performance concerning the aquaculture sector was implemented. Finally, 71 projects were selected, 68 corresponding to those entered to the EAS as EID and three as EIS. The PCO analysis only considered the 68 EID projects.

The PCO analysis also explored how each regulatory stage (SD30, SD95, and SD40) determines the variability of the selected 68 EID projects, and the patterns between projects through their relationships with 12 selected indicators. The first factorial plane (PCO1 and PCO2) explained $55.2 \%$ of the total variance through two data groups. Group 1 included projects from the first (SD30) and second (SD95) regulatory stages, and group 2 from the most recent third (SD40) regulatory stage [19,20,23].

This analysis displays how the progressive regulatory improvements during the three successive stages had a noticeable influence over indicators Processing times (A), Description and justification of the influence area (B), Professionals who prepared reports (C), and Consultation and participation $(\mathrm{J})$. As conclusion, projects submitted under the third regulatory stage (SD40) presented better performance indicators than those under the two former stages (SD30 and SD95), thus showing that the introduced measures to increase the performance of the Chilean EIS system are positive.

Nonetheless, the Chilean EIA system can further be improved from a sociocultural perspective. The main opportunities for improvement are through incorporating the following items: synergistic and cumulative effects, adaptation to climate change, development of a general methodology for project evaluation, and incorporation of early participation in projects with environmental charges $[27,54,55,62]$. These improvement opportunities will allow increasing both the administrative requirements of the EIA and the cultural aspects, which will allow to increase the performance and also the confidence of the EIA. These issues are the most typically questioned by different society actors.

The introduced methodology enables for reliable comparisons of the environmental regulations evolution, and how this affects the Chilean EIA system performance in aquaculture projects, considering that the environmental regulation is a relevant aspect to achieve the sustainability of the item. It is a tedious task frequently avoided due to the absence of a confident methodological route. This paper also sought to offer a feasible methodological guide to evaluate the performance of the EIA system with a cultural focus in other activities and countries.

Regarding the research limitations, this study aimed at looking for patterns in the administrative structure in the period 1994-2019. For this, the attributes of the reviewed reports were categorized taking into account that resolution could eventually be lost in the analysis of the individual aspects of the study.

Author Contributions: Conceptualization, D.R.-L.; investigation, D.R.-L.; methodology, D.R.-L., N.V., F.J.A. and F.E.-M.; writing original draft, D.R.-L.; supervision, N.V., F.J.A. and F.E.-M.; reviewing and editing, N.V., F.J.A. and F.E.-M. All authors have read and agreed to the published version of the manuscript.

Funding: This research received no external funding.

Institutional Review Board Statement: Not applicable.

Informed Consent Statement: Not applicable.

Data Availability Statement: All data, models, and code generated or used during the study appear in the submitted article.

Conflicts of Interest: The authors declare no conflict of interest. 


\section{Appendix A}

Table A1. For the period 1994-2019 in Chile, number and status of EIS and EID aquaculture projects by region. Information compiled from the EAS website, accessed on 26 December 2020 [https://www.sea.gob.cl/].

\begin{tabular}{|c|c|c|c|c|c|c|c|c|c|c|c|c|c|c|c|c|c|}
\hline \multirow[t]{2}{*}{ Region $^{1}$} & \multicolumn{2}{|c|}{$\begin{array}{l}\bar{d} \\
0 \\
0 \\
\frac{0}{2} \\
\frac{2}{2}\end{array}$} & \multicolumn{2}{|c|}{ 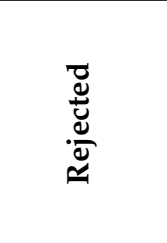 } & \multicolumn{2}{|c|}{ 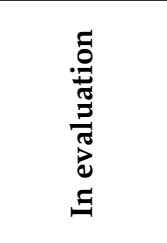 } & \multicolumn{2}{|c|}{ 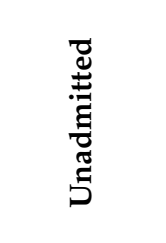 } & \multicolumn{2}{|c|}{ 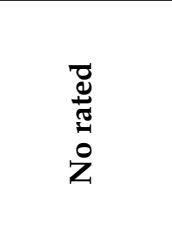 } & \multicolumn{2}{|c|}{ 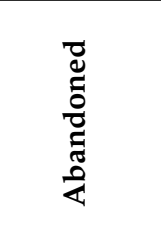 } & \multicolumn{2}{|c|}{ 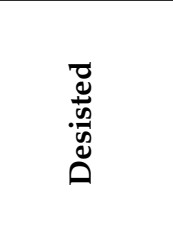 } & \multicolumn{2}{|c|}{ 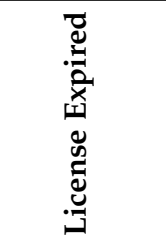 } & \multirow[t]{2}{*}{$\underset{\tilde{0}}{\tilde{0}}$} \\
\hline & EIS & EID & EIS & EID & EIS & EID & EIS & EID & EIS & EID & EIS & EID & EIS & EID & EIS & EID & \\
\hline $\begin{array}{c}\mathrm{XV} \text {, Arica and } \\
\text { Parinacota }\end{array}$ & & 19 & & & & & & 5 & & 1 & & & & & & & 25 \\
\hline I, Tarapacá & & 41 & & & & & & 9 & & 1 & & 2 & & 4 & & & 57 \\
\hline II, Antofagasta & & 10 & & 4 & & & & 4 & & & & & & 2 & & & 20 \\
\hline III, Atacama & & 70 & & 10 & & & & 31 & & 7 & & & & 7 & & & 125 \\
\hline IV, Coquimbo & 1 & 45 & 1 & 1 & & & 4 & 24 & 1 & & & 1 & & 12 & & & 90 \\
\hline V, Valparaíso & & 12 & & 1 & & & & 12 & & & & & & 8 & & & 33 \\
\hline RM, Metropolitan & & 4 & & & & & & 1 & & & & & & 1 & & & 6 \\
\hline VI, O'Higgins & & 3 & & & & & & & & & & & & & & & 3 \\
\hline VII, Maule & & 13 & & 2 & & & & 4 & & & & & & 4 & & & 23 \\
\hline XVI, Nuble & & 3 & & 3 & & & & 2 & & & & & & 9 & & & 17 \\
\hline VIII, Bio Bio & & 75 & & 3 & & & & 9 & & 15 & & & & 13 & & & 115 \\
\hline IX, La Araucanía & & 86 & & 12 & & & & 28 & & 3 & & & & 16 & & & 145 \\
\hline XIV, Los Ríos & 1 & 65 & & 16 & & 1 & & 15 & & 16 & & 2 & 1 & 18 & & & 135 \\
\hline X, Los Lagos & 3 & 1895 & & 128 & 1 & 1 & & 74 & & 15 & & 3 & 5 & 129 & & 3 & 2257 \\
\hline XI, Aysén & 8 & 1074 & & 274 & & & 6 & 317 & & 28 & & & 3 & 146 & & 6 & 1862 \\
\hline XII, Magallanes & & 230 & & 39 & & 3 & & 21 & & 3 & & & & 90 & & & 386 \\
\hline Interregional & & 10 & & 4 & & & & 6 & & 1 & & & & 3 & & & 24 \\
\hline Total & 13 & 3631 & 1 & 497 & 1 & 6 & 10 & 562 & 1 & 90 & 0 & 8 & 9 & 462 & 0 & 32 & 5323 \\
\hline
\end{tabular}

Table A2. Coordinates of the principal coordinate (PCO) analysis.

\begin{tabular}{|c|c|c|c|c|c|c|c|c|c|c|}
\hline & PCO1 & $\mathrm{PCO} 2$ & $\mathrm{PCO} 3$ & $\mathrm{PCO} 4$ & PCO5 & PCO6 & PCO7 & PCO8 & PCO9 & PCO10 \\
\hline Project (P1-P71) & 37.70 & 17.39 & 11.65 & 9.64 & 7.98 & 6.59 & 4.07 & 2.93 & 1.65 & 0.32 \\
\hline P1 & -0.024 & -0.168 & 0.292 & -0.056 & 0.023 & -0.224 & -0.126 & -0.007 & 0.000 & 0.031 \\
\hline P2 & -0.146 & 0.559 & 0.039 & -0.232 & -0.117 & -0.157 & -0.105 & -0.075 & 0.092 & 0.047 \\
\hline P3 & -0.565 & -0.393 & 0.156 & 0.368 & -0.162 & 0.033 & -0.078 & 0.012 & 0.066 & -0.015 \\
\hline $\mathrm{P} 4$ & 0.230 & 0.772 & -0.206 & -0.231 & 0.244 & 0.011 & 0.155 & -0.138 & -0.004 & 0.003 \\
\hline P5 & 0.365 & 0.222 & 0.316 & 0.270 & -0.289 & 0.092 & 0.016 & -0.105 & 0.021 & 0.012 \\
\hline P6 & -0.709 & 0.293 & 0.166 & -0.070 & -0.222 & 0.036 & -0.112 & -0.096 & 0.139 & 0.032 \\
\hline P7 & 0.007 & -0.244 & 0.227 & -0.127 & 0.011 & -0.141 & -0.196 & 0.025 & 0.007 & 0.033 \\
\hline P11 & -0.165 & -0.034 & 0.593 & -0.151 & 0.095 & 0.084 & 0.307 & 0.201 & 0.132 & 0.054 \\
\hline P12 & -0.076 & -0.196 & 0.461 & -0.113 & 0.226 & 0.073 & 0.034 & -0.126 & -0.054 & 0.012 \\
\hline P13 & -1.208 & 0.133 & -0.306 & 0.224 & 0.055 & 0.152 & 0.088 & -0.057 & 0.130 & -0.044 \\
\hline P14 & -0.286 & 0.203 & 0.135 & -0.578 & 0.083 & 0.415 & -0.173 & -0.117 & 0.059 & 0.040 \\
\hline P15 & -0.412 & -0.251 & 0.266 & 0.185 & 0.032 & -0.173 & -0.017 & -0.031 & 0.017 & 0.002 \\
\hline P16 & -0.434 & -0.206 & 0.157 & 0.052 & 0.026 & -0.079 & -0.081 & -0.014 & 0.037 & 0.007 \\
\hline P17 & -0.253 & 0.021 & 0.164 & -0.350 & 0.277 & -0.230 & -0.082 & -0.045 & -0.004 & 0.034 \\
\hline P18 & -0.553 & 0.306 & 0.063 & -0.201 & 0.118 & 0.325 & 0.051 & -0.162 & 0.060 & 0.000 \\
\hline P19 & -0.296 & -0.461 & -0.023 & -0.093 & 0.143 & 0.029 & -0.187 & 0.072 & 0.013 & 0.000 \\
\hline P20 & -0.434 & -0.206 & 0.157 & 0.052 & 0.026 & -0.079 & -0.081 & -0.014 & 0.037 & 0.007 \\
\hline P21 & -0.241 & -0.086 & -0.106 & 0.007 & 0.257 & -0.186 & 0.008 & 0.013 & -0.007 & -0.011 \\
\hline P22 & -0.194 & -0.037 & -0.302 & -0.124 & 0.585 & -0.297 & 0.104 & 0.021 & -0.062 & -0.026 \\
\hline P23 & -0.100 & -0.033 & -0.059 & 0.195 & -0.071 & -0.110 & -0.063 & 0.028 & 0.040 & -0.004 \\
\hline P24 & -0.107 & 0.621 & -0.338 & 0.084 & -0.162 & -0.094 & -0.016 & -0.020 & 0.107 & 0.003 \\
\hline
\end{tabular}


Table A2. Cont.

\begin{tabular}{|c|c|c|c|c|c|c|c|c|c|c|}
\hline & PCO1 & $\mathrm{PCO} 2$ & $\mathrm{PCO} 3$ & $\mathrm{PCO} 4$ & PCO5 & PCO6 & PCO7 & PCO8 & PCO9 & PCO10 \\
\hline $\mathrm{P} 25$ & -0.120 & 0.585 & -0.067 & -0.304 & 0.062 & -0.218 & -0.053 & -0.070 & 0.063 & 0.039 \\
\hline P26 & -0.060 & 0.574 & -0.478 & -0.033 & -0.036 & -0.068 & -0.038 & 0.013 & 0.090 & -0.001 \\
\hline $\mathrm{P} 27$ & 0.099 & -0.094 & 0.270 & -0.108 & 0.334 & 0.007 & 0.087 & -0.103 & -0.078 & 0.000 \\
\hline P28 & 0.469 & 0.073 & 0.193 & 0.200 & -0.111 & 0.077 & 0.014 & -0.060 & -0.020 & 0.001 \\
\hline P29 & 0.480 & 0.028 & -0.159 & -0.214 & -0.148 & 0.432 & -0.252 & 0.037 & 0.036 & 0.015 \\
\hline P30 & 0.485 & 0.089 & 0.128 & 0.156 & -0.002 & 0.041 & 0.046 & -0.057 & -0.038 & -0.004 \\
\hline P31 & 0.401 & 0.349 & -0.067 & -0.051 & 0.153 & 0.038 & 0.083 & -0.077 & -0.032 & -0.003 \\
\hline P32 & 0.534 & 0.032 & -0.011 & 0.036 & 0.110 & 0.081 & 0.013 & -0.021 & -0.052 & -0.008 \\
\hline P33 & 0.612 & -0.182 & -0.164 & -0.142 & 0.033 & 0.321 & -0.190 & 0.066 & -0.027 & -0.001 \\
\hline P34 & -0.089 & -0.251 & 0.068 & 0.094 & 0.200 & 0.223 & 0.051 & -0.049 & -0.035 & -0.028 \\
\hline P35 & 0.255 & 0.159 & -0.218 & 0.254 & 0.146 & 0.107 & 0.155 & -0.039 & -0.032 & -0.042 \\
\hline P36 & 0.469 & 0.168 & 0.138 & 0.187 & 0.089 & -0.059 & 0.131 & -0.084 & -0.058 & -0.009 \\
\hline P37 & 0.217 & -0.063 & -0.410 & 0.103 & -0.074 & 0.017 & -0.176 & 0.130 & 0.042 & -0.012 \\
\hline P38 & 0.364 & -0.127 & -0.278 & 0.190 & 0.060 & 0.284 & -0.011 & 0.041 & -0.022 & -0.039 \\
\hline P39 & 0.473 & 0.236 & -0.003 & -0.082 & 0.200 & 0.008 & 0.358 & 0.308 & 0.096 & 0.025 \\
\hline $\mathrm{P} 40$ & 0.584 & -0.044 & -0.145 & -0.087 & 0.190 & 0.147 & -0.042 & 0.019 & -0.060 & -0.010 \\
\hline P41 & -0.007 & 0.010 & 0.043 & 0.225 & 0.033 & 0.190 & 0.089 & -0.073 & -0.004 & -0.026 \\
\hline $\mathrm{P} 42$ & -0.291 & -0.660 & -0.310 & -0.497 & -0.224 & 0.091 & 0.092 & -0.168 & -0.035 & -0.010 \\
\hline P43 & 0.380 & 0.089 & -0.117 & -0.034 & -0.068 & -0.171 & -0.165 & 0.067 & 0.019 & 0.021 \\
\hline P44 & -0.548 & 0.405 & 0.467 & -0.394 & -0.342 & -0.018 & 0.058 & 0.422 & -0.108 & -0.114 \\
\hline P45 & -0.039 & -0.184 & 0.355 & -0.014 & -0.082 & -0.188 & -0.157 & -0.010 & 0.018 & 0.036 \\
\hline P46 & 0.455 & 0.058 & 0.252 & 0.239 & -0.209 & 0.111 & -0.015 & -0.063 & -0.004 & 0.006 \\
\hline P47 & 0.495 & -0.008 & 0.148 & 0.142 & -0.157 & 0.171 & -0.065 & -0.028 & -0.008 & 0.004 \\
\hline P48 & 0.343 & -0.042 & -0.136 & -0.152 & -0.491 & -0.312 & 0.269 & -0.247 & -0.046 & 0.007 \\
\hline P49 & 0.386 & 0.040 & 0.049 & 0.141 & -0.144 & -0.247 & -0.117 & 0.043 & 0.012 & 0.020 \\
\hline P50 & 0.483 & 0.083 & 0.212 & 0.097 & -0.078 & 0.079 & 0.280 & 0.312 & 0.128 & 0.034 \\
\hline P51 & 0.505 & 0.002 & 0.107 & 0.115 & -0.088 & 0.148 & -0.045 & -0.027 & -0.019 & 0.001 \\
\hline P52 & -0.205 & -0.101 & 0.231 & 0.195 & -0.032 & 0.247 & 0.045 & -0.099 & 0.014 & -0.015 \\
\hline P53 & 0.524 & -0.420 & -0.396 & -0.393 & -0.430 & -0.065 & 0.045 & -0.112 & -0.054 & 0.005 \\
\hline P54 & -0.213 & -0.419 & -0.078 & -0.072 & -0.287 & -0.232 & 0.346 & -0.260 & -0.063 & -0.022 \\
\hline P55 & -0.083 & -0.690 & -0.307 & -0.443 & -0.293 & 0.075 & 0.353 & 0.232 & 0.109 & 0.017 \\
\hline P56 & 0.273 & -0.116 & 0.245 & 0.003 & 0.006 & 0.161 & -0.050 & -0.055 & -0.026 & 0.008 \\
\hline P57 & 0.107 & -0.385 & -0.425 & -0.117 & 0.169 & 0.077 & -0.236 & 0.167 & 0.003 & -0.014 \\
\hline P58 & 0.428 & -0.024 & -0.062 & 0.039 & -0.079 & -0.191 & -0.165 & 0.077 & 0.006 & 0.018 \\
\hline P59 & -0.089 & -0.251 & 0.068 & 0.094 & 0.200 & 0.223 & 0.051 & -0.049 & -0.035 & -0.028 \\
\hline P60 & 0.167 & -0.042 & -0.084 & 0.418 & -0.274 & -0.110 & -0.086 & 0.065 & 0.050 & -0.009 \\
\hline P61 & -0.219 & -0.225 & 0.055 & 0.151 & 0.069 & -0.146 & -0.043 & 0.019 & 0.009 & -0.006 \\
\hline P62 & 0.349 & 0.164 & -0.052 & 0.038 & -0.055 & -0.254 & -0.096 & 0.034 & 0.013 & 0.019 \\
\hline P63 & -0.234 & -0.146 & 0.064 & 0.181 & 0.160 & -0.246 & 0.042 & -0.008 & -0.010 & -0.011 \\
\hline P64 & -0.207 & -0.213 & 0.007 & 0.118 & 0.149 & -0.173 & -0.020 & 0.021 & -0.005 & -0.009 \\
\hline P65 & 0.524 & 0.129 & -0.033 & 0.048 & 0.269 & -0.051 & 0.125 & -0.050 & -0.083 & -0.016 \\
\hline P66 & 0.216 & 0.009 & -0.290 & 0.280 & 0.071 & -0.227 & 0.015 & 0.074 & -0.008 & -0.025 \\
\hline P67 & -0.217 & -0.169 & -0.142 & -0.045 & 0.196 & -0.087 & -0.076 & 0.044 & 0.007 & -0.007 \\
\hline P68 & -0.217 & -0.169 & -0.142 & -0.045 & 0.196 & -0.087 & -0.076 & 0.044 & 0.007 & -0.007 \\
\hline P69 & -0.387 & 0.496 & 0.258 & -0.287 & -0.266 & -0.085 & -0.155 & 0.073 & -0.279 & -0.158 \\
\hline P70 & -1.152 & 0.251 & -0.338 & 0.313 & -0.162 & 0.206 & 0.083 & 0.178 & -0.465 & 0.181 \\
\hline P71 & -1.096 & 0.179 & -0.299 & 0.344 & -0.142 & 0.193 & 0.049 & -0.044 & 0.158 & -0.041 \\
\hline
\end{tabular}

\section{References}

1. Subasinghe, R.; Soto, D.; Jia, J. Global aquaculture and its role in sustainable development. Rev. Aquac. 2009, 1, 2-9. [CrossRef]

2. FAO. El Estado Mundial de la Pesca y la Acuicultura 2020: La Sostenibilidad en Acción; FAO: Roma, Italy, 2020. [CrossRef]

3. Akenji, L.; Bengtsson, M. Making sustainable consumption and production the core of sustainable development goals. Sustainability 2014, 6, 513-529. [CrossRef]

4. Ilieva, R.T. Urban Food Systems Strategies: A Promising Tool for Implementing the SDGs in Practice. Sustainability 2017, 9, 1707. [CrossRef]

5. United Nations. Sustainability Development Goals. 17 Goals to Transform Our World; United Nations: New York, NY, USA, 2021. Available online: https://www.un.org/sustainabledevelopment/ (accessed on 1 May 2021). 
6. SERNAPESCA. Anuario Estadístico de Pesca y Acuicultura, Servicio Nacional de Pesca y Acuicultura; Gobierno de Chile: Santiago, Chile, 2019.

7. Quiñones, R.A.; Fuentes, M.; Montes, R.M.; Soto, D.; León-Muñoz, J. Environmental issues in Chilean salmon farming: A review. Rev. Aquac. 2019, 11, 375-402. [CrossRef]

8. Alvarado-Flores, C.; Encina-Montoya, F.; Tucca, F.; Vega-Aguayo, R.; Nimptsch, J.; Oberti, C.; Carmona, E.; Luders, C. Assessing the ecological risk of active principles used currently by freshwater fish farms. Sci. Total Environ. 2021, 775, 144716. [CrossRef] [PubMed]

9. CORFO. Hoja de Ruta Programa Estratégico Nacional-Acuicultura. Resumen Ejecutivo; Gobierno de Chile: Santiago, Chile, 2016.

10. Nimptsch, J.; Woelfl, S.; Osorio, S.; Valenzuela, J.; Ebersbach, P.; Von Tuempling, W.; Palma, R.; Encina-Montoya, F.; Figueroa, D.; Kamjunke, N.; et al. Tracing dissolved organic matter (DOM) from land-based aquaculture systems in North Patagonian streams. Sci. Total Environ. 2015, 537, 129-138. [CrossRef] [PubMed]

11. Kamjunke, N.; Nimptsch, J.; Harir, M.; Herzsprung, P.; Schmitt-Koppling, P.; Neu, T.; Graeber, D.; Osorio, S.; Valenzuela, J.; Reyes, J.C.; et al. Land-based salmon aquacultures change the quality and bacterial degradation of riverine dissolved organic matter. Sci. Rep. 2017, 7, 43739. [CrossRef]

12. Tello, A.; Corner, R.A.; Telfer, T.C. How do land-based salmonid farms affect stream ecology? Environ. Pollut. 2010, 158, 1147-1158. [CrossRef]

13. Encina-Montoya, F.; Boyero, L.; Tonin, A.; Aguayo, M.; Esse, C.; Vega, R.; Correa-Araneda, F.; Oberti, C.; Nimptsch, J. Relationship between salt use in fish farms and drift of macroinvertebrates in a freshwater stream. Aquac. Environ. Interact. 2020, 12, 205-213. [CrossRef]

14. Soto, D.; León-Muñoz, J.; Dresdner, J.; Luengo, C.; Tapia, F.; Garreaud, R. Salmon farming vulnerability to climate change in southern Chile: Understanding the biophysical, socioeconomic and governance links. Rev. Aquac. 2019, 11, 354-374. [CrossRef]

15. Chen, M.; Bi, R.; Chen, X.; Ding, Y.; Zhang, H.; Li, L.; Zhao, M. Stoichiometric and sterol responses of dinoflagellates to changes in temperature, nutrient supply and growth phase. Algal Res. 2019, 42, 101609. [CrossRef]

16. Bacher, K. GLOBEFISH consultant. Perceptions and Misconceptions of Aquaculture: A Global Overview; GLOBEFISH Research Programme; FAO: Rome, Italy, 2015; Volume 120.

17. Alfaro, D.; Peña-Cortés, F. Potencial acuícola en áreas preandinas de la Región de La Araucanía: Conflictos de uso con la actividad turística. Rev. Geogr. Norte Gd. 2012, 51, 137-157. [CrossRef]

18. Vallejos, A.; Oyarzún, I.; Garrido, J. Salmonicultura 2.0 en Chile: Una mirada desde la gobernanza ambiental. Rev. Venez. Gerenc. 2014, 19, 116-137. [CrossRef]

19. Ministerio Secretaría General de la Presidencia. Decreto Supremo No 30 Reglamento del Sistema de Evaluación de Impacto Ambiental (derogado); Gobierno de Chile: Santiago, Chile, 1997.

20. Ministerio Secretaría General de la Presidencia. Decreto Supremo N 95 Reglamento del Sistema de Evaluación de Impacto Ambiental (derogado); Gobierno de Chile: Santiago, Chile, 2001.

21. Ministerio Secretaría General de la Presidencia. Ley 19.300, Sobre Bases Generales de Medio Ambiente; Gobierno de Chile: Santiago, Chile, 1994.

22. Ministerio Secretaría General de la Presidencia. Ley 20.417 Crea el Ministerio del Medio Ambiente, el Servicio de Evaluación Ambiental y la Superintendencia de Medio Ambiente; Gobierno de Chile: Santiago, Chile, 2010.

23. Ministerio del Medio Ambiente. Decreto Supremo $N^{\circ} 40$ Reglamento del Sistema de Evaluación de Impacto Ambiental; Gobierno de Chile: Santiago, Chile, 2012.

24. Ministerio Secretaría General de la Presidencia. Decreto Supremo $N^{\circ} 90$ Establece Norma de Emisión Para la Regulación de Contaminantes Asociados a Las Descargas de Residuos Líquidos a Aguas Marinas y Continentales Superficiales; Gobierno de Chile: Santiago, Chile, 2000.

25. Ministerio de Economía, Fomento y Reconstrucción; Subsecretaría de Pesca. Decreto Supremo N 320 Reglamento Ambiental Para la Acuicultura; Gobierno de Chile: Santiago, Chile, 2001.

26. Ministerio de Economía, Fomento y Reconstrucción; Subsecretaría de Pesca. Decreto Supremo N³19 Aprueba Reglamento de Medidas de Protección, Control y Erradicación de Enfermedades de Alto Riesgos Para Las Especies Hidrobiológicas, Deroga Decreto N²162, de 1985; Gobierno de Chile: Santiago, Chile, 2001.

27. Comisión Asesora Presidencial para la Evaluación del SEIA. Technical Report; Gobierno de Chile: Santiago, Chile, 2017.

28. Rungruangsakorn, C. El rol del Estado chileno en los proyectos de inversión productiva y los conflictos socioambientales: Una aproximación cuantitativa. Colomb. Int. 2021, 105, 147-173. [CrossRef]

29. Instituto Nacional de Derechos Humanos. Mapa de Conflictos Socioambientales en Chile al Año 2018; Santiago, Chile, 2018. Available online: https:/ / mapaconflictos.indh.cl/\#/ (accessed on 1 December 2020).

30. Carranza, D.; Varas-Belemmi, K.; De Veer, D.; Iglesias-Müller, C.; Coral-Santacruz, D.; Méndez, F.; Torres-Lagos, E.; Squeo, F.; Gaymer, C. Socio-environmental conflicts: An underestimated threat to biodiversity conservation in Chile. Environ. Sci. Policy 2020, 110, 46-59. [CrossRef]

31. Rodríguez-Luna, D.; Vela, N.; Alcalá, F.J.; Encina-Montoya, F. The environmental impact assessment in Chile: Overview, improvements, and comparisons. Environ. Impact Assess. Rev. 2021, 86, 106502. [CrossRef]

32. Wood, C. Evaluación de Impacto Ambiental un análisis comparativo de ocho Sistemas EIA; Doc de trabajo $\mathrm{N}^{\circ}$ 247; Centro de Estudios Públicos: Santiago, Chile, 1995. 
33. Annandale, D. Developing and evaluating environmental impact assessment systems for small developing countries. Impact Assess. Proj. Apprais. 2001, 19, 187-193. [CrossRef]

34. Ahmad, B.; Wood, C. A comparative evaluation of the EIA systems in Egypt, Turkey and Tunisia. Environ. Impact Assess. Rev. 2002, 22, 213-234. [CrossRef]

35. Khosravi, F.; Jha-Thakur, U.; Fischer, B. Evaluation of the environmental impact assessment system in Iran. Environ. Impact Assess. Rev. 2019, 74, 63-72. [CrossRef]

36. Lacy, S. Can environmental impact assessments alone conserve freshwater fish biota? Review of the Chilean experience. Environ. Impact Assess. Rev. 2017, 63, 87-94. [CrossRef]

37. Campero, C.; Harris, L.; Kunz, N. De-politicising seawater desalination: Environmental Impact Assessments in the Atacama mining Region, Chile. Environ. Sci. Policy 2021, 120, 187-194. [CrossRef]

38. Otzen, T.; Manterola, C. Técnicas de Muestreo sobre una Población a Estudio. Int. J. Morphol. 2017, 35, 227-232. [CrossRef]

39. López-Roldan, P.; Fachelli, S. Metodología de la Investigación Social Cuantitativa; Universidad Autónoma de Barcelona: Barcelona, Spain, 2015; Edición Digital. Available online: http:/ / ddd.uab.cat/record/129382 (accessed on 1 December 2020).

40. Taherdoost, H. Sampling Methods in Research Methodology; How to Choose a Sampling Technique for Research. Int. J. Acad. Res. Manag. 2016, 5, 18-27. [CrossRef]

41. Arvidsson, R. On the use of ordinal scoring scales in social life cycle assessment. Int. J. Life Cycle Assess. 2019, 24, 604-606. [CrossRef]

42. Fayers, P.M.; Hand, D.J. Causal variables, indicator variables and measurement scales: An example from quality of life. J. R. Stat. Soc. Ser. A (Stat. Soc.) 2002, 165, 233-253. [CrossRef]

43. Gower, J.C. A Q-technique for the calculation of canonical variates. Biometrika 1966, 53, 588-590. [CrossRef]

44. Anderson, M.J.; Willis, T.J. Canonical Analysis of Principal Coordinates: A useful Method of constrained ordination for Ecology. Ecology 2003, 84, 511-525. [CrossRef]

45. Clarke, K.; Gorley, R.; Somerfield, P.; Warwick, R. Change in Marine Communities: An Approach to Statistical Analysis and Interpretation, 3rd ed.; Primer-E Ltd.: Plymouth, UK, 2014.

46. Linazasoro, I.; Pelayo, C. Control de Admisibilidad en el ingreso al SEIA: Análisis del estado actual de la no admisión a trámite de proyectos. Rev. Derecho Ambient. 2019, 11, 1-18. [CrossRef]

47. Méndez, P. Algunas precisiones sobre el término anticipado del procedimiento de evaluación ambiental. Rev. Derecho 2016, 29, 141-159. [CrossRef]

48. Servicio de Evaluación Ambiental. Guía de Evaluación de Impacto Ambiental Para la Descripción del Uso del Territorio en el Sistema de Evaluación de Impacto Ambiental; Gobierno de Chile: Santiago, Chile, 2013.

49. Servicio de Evaluación Ambiental. Guía Para la Descripción de Los Componentes Suelo, Flora y Fauna de Ecosistemas Terrestres en el Sistema de Evaluación de Impacto Ambiental; Gobierno de Chile: Santiago, Chile, 2015.

50. Servicio de Evaluación Ambiental. Guía Para la Descripción de la Calidad del Aire en el Área de Influencia de Proyecto que Ingresan al Sistema de Evaluación de Impacto Ambiental; Gobierno de Chile: Santiago, Chile, 2015.

51. Servicio de Evaluación Ambiental. Guía Sobre el área de Influencia en el Sistema de Evaluación de Impacto Ambiental; Gobierno de Chile: Santiago, Chile, 2017.

52. Servicio de Evaluación Ambiental. Guía Área de Influencia de Los Sistemas de Vida y Costumbres de Grupos Humanos en el Sistema de Evaluación de Impacto Ambiental; Gobierno de Chile: Santiago, Chile, 2020.

53. Lara, M.; Letelier, D. Mecanismos de participación ciudadana en el sistema de evaluación de impacto ambiental chileno. Rev. Gest. Pública 2020, 6, 283. [CrossRef]

54. Roudgarmi, P. Cumulative Effects Assessment (CEA), A Review. J. Environ. Assess. Policy Manag. 2018, 20, 1850008. [CrossRef]

55. Connelly, R.B. Canadian and international EIA frameworks as they apply to cumulative effects. Environ. Impact Assess. Rev. 2011, 31, 453-456. [CrossRef]

56. Williams, C.J.R. Climate Change in Chile: An Analysis of State-of-the-Art Observations, Satellite-Derived Estimates and Climate Model Simulations. J. Earth Sci. Clim. Chang. 2017, 8, 400. [CrossRef]

57. Araya-Osses, D.; Casanueva, A.; Román-Figueroa, C.; Uribe, J.; Paneque, M. Climate change projections of temperature and precipitation in Chile based on statistical downscaling. Clim. Dyn. 2020, 54, 4309-4330. [CrossRef]

58. Gajardo, P. Reflexiones en torno a la consideración del cambio climático en la evaluación de impacto ambiental. Rev. Derecho Ambient. 2019, 12, 109-132. [CrossRef]

59. Lonsdale, J.; Weston, K.; Blake, S.; Edwards, R.; Elliott, M. The Amended European Environmental Impact Assessment Directive: UK marine experience and recommendations. Ocean Coast. Manag. 2017, 148, 131-142. [CrossRef]

60. Aldunce, P.; Araya, D.; Sapiain, R.; Ramos, I.; Lillo, G.; Urquiza, A.; Garreaud, R. Local Perception of Drought Impacts in a Changing Climate: The Mega-Drought in Central Chile. Sustainability 2017, 9, 2053. [CrossRef]

61. André, P.; Enserink, B.; Connor, D.; Croal, P. Public Participation International Best Practice Principles; Special Publication Series No. 4; International Association for Impact Assessment: Fargo, ND, USA, 2006. Available online: http://www.jsia.net/6_assessment/ fastips/SP4_Public\%20Participation.pdf (accessed on 1 December 2020).

62. Ocampo-Melgar, A.; Sagaris, L.; Gironás, J. Experiences of voluntary early participation in Environmental Impact Assessments in Chilean mining. Environ. Impact Assess. Rev. 2019, 74, 43-53. [CrossRef] 
63. Bice, S.; Moffat, K. Social licence to operate and impact assessment. Impact Assess. Proj. Apprais. 2014, 32, 257-262. [CrossRef]

64. Moeremans, B.; Dooms, M. An Exploration of Social License to Operate (SLTO) Measurement in the Port Industry: The Case of North America. Sustainability 2021, 13, 2543. [CrossRef] 